Research Article

\title{
SUPPLEMENTATION OF CORN-SOYBEAN BASED LAYERS DIETS WITH DIFFERENT LEVELS OF ACID PROTEASE
}

\author{
J. L. Yadav and R. A. Sah \\ Institute of Agriculture and Animal Sciences, Rampur, Chitwan, Nepal
}

\begin{abstract}
An experiment was conducted at the Animal Science Farm, Tuntungin, Putho of the Institute of Animal Science, University of the Philippines, Los Baños, College, Laguna, Philippines, during 2001-2002. Ninety 24-weeks old individually caged pullets were used in this study. Five treatments were randomly assigned to the 90 pullets following a completely randomized design. Each treatment was replicated 18 times with one pullet each. The dietary treatments were: basal diet (18\% CP and $2800 \mathrm{kcal} / \mathrm{kg}, \mathrm{ME})$ reduced (red). CP diet $(17 \% \mathrm{CP}$ and $2800 \mathrm{kcal} / \mathrm{kg}$, ME), red CP diet $+0.05 \%$ protease, red CP diet $+0.075 \%$ protease and red CP diet $+0.10 \%$ protease. Apparent digestibility of each nutrient in relation to egg production, egg weight, feed consumption, feed efficiency, body weight gain, shell thickness and yolk pigmentation, mortality, and income over feed cost were calculated All the data collected were subjected to statistical analysis using the general linear model (GLM) procedure of the SAS Institute (1988). One percent reduction of crude protein of diet of pullet significantly decreased the digestibility of all nutrients. Feed efficiency was significantly improved with $0.1 \%$ protease, while eggshell thickness was significantly improved with $0.075 \%$ protease supplementation of diets. Income over feed cost increased with dietary supplementation of protease. Increased level of protease supplementation of reduced CP diets consistently improved the digestibility of nutrients, overall average egg production and decreased feed consumption. Egg weight and feed efficiency were slightly improved with $0.075 \%$ and $0.1 \%$ protease supplementation of diet. Eggshell thickness was significantly improved with $0.075 \%$ protease Yolk color was not significantly influenced by increased protease supplementation of the diet. Income over feed cost was consistently increased with protease supplementation. It was concluded and recommended that crude protein of layer diets could be reduced by $1 \%$ provided that they are supplemented with protease, optimum level of inclusion of protease is $0.1 \%$ for layers and enzyme activity need to be accurately determined before it is used.
\end{abstract}

Key words: Layer, corn-based, acid protease, enzyme

\section{INTRODUCTION}

It has been well established that supplementing feeds with enzymes improves the efficiency of production, enhances the use of lower quality feedstuffs and reduces the excretion and waste of nutrients. (Close, 1996). The nutritional problems associated with cereal grains have been overcome by addition of feed enzymes. Studies have shown that the nutritive value of barley, oats, rye, corn and wheat can be considerably improved by the dietary inclusions of commercially available crude enzyme preparations (Marquardt et al., 1994). Enzyme supplementation can break down anti-nutritional substances found in feed raw materials, thus augmenting the digestive capacity of the animal, improving availability of the feed nutrients, and increasing release of nutrients in the upper part of the gastrointestinal tract. Improvements in the efficiency of utilization of poultry diets and nutrients of about $10 \%$ have been reported to be achieved as a result of supplementation with enzymes (Cowieson et al., 2000). A study was conducted to find out the effects of supplementation of corn-soy based layers diet with acid protease on its performance mainly on growth, feed consumption, nutrients digestibility and economics of production.

\section{MATERIALS AND METHODS}

Ninety 24-weeks old individually caged pullets were used in this study. Five treatments were randomly assigned to the 90 pullets following a completely randomized design. Each treatment was replicated 18 times with one pullet each. The dietary treatments were: basal diet $(18 \% \mathrm{CP}$ and $2800 \mathrm{kcal} / \mathrm{kg}, \mathrm{ME})$, red CP diet (17 $\% \mathrm{CP}$ and $2800 \mathrm{kcal} / \mathrm{kg}, \mathrm{ME})$ red CP diet $+0.05 \%$ protease, red CP diet $+0.075 \%$ protease, and red CP diet 
$+0.10 \%$ protease. A basal layer diet was formulated to contain $18 \%$ crude protein and $2800 \mathrm{kcal} / \mathrm{kg}$, ME supplemented with required vitamins, minerals and amino acids. The diets with reduced $\mathrm{CP}$ was formulated to contain $17 \% \mathrm{CP}$ and $2800 \mathrm{kcal} / \mathrm{kg}, \mathrm{ME}$ and likewise supplemented with required vitamins, minerals and amino acids. The different levels of protease were added to the diet with the reduced $\mathrm{CP}$ at the desired level $(0.00 \%$, $0.05 \%, 0.075 \%$, and $0.1 \%$ ). The ingredient composition and calculated nutrient contents of the diets are presented in Table 1.

Table 1. Ingredient composition and calculated nutrient contents of basal diet and diets with reduced crude protein of layers

\begin{tabular}{|lcc|}
\hline Ingredients & Basal diet (\%) & Reduced CP diet (\%) \\
\hline Corn yellow & 50.50 & 50.90 \\
Soybean yellow, US & 27.60 & 24.70 \\
Rice bran DI & 7.61 & 10.10 \\
Lime stone, fine & 5.70 & 5.70 \\
Limestone, coarse & 4.00 & 4.00 \\
Crude coco oil & 2.00 & 2.00 \\
Biophos/TG21 & 1.70 & 1.70 \\
Salt & 0.30 & 0.30 \\
Chorine chloride & 0.25 & 0.25 \\
DL-Methionine & 0.17 & 0.18 \\
Vitamin premix & 0.125 & 0.125 \\
Mineral premix & 0.100 & 0.100 \\
Total & 100.00 & 100.00 \\
Calculated Analysis & & \\
Crude protein (\%) & 18.00 & 17.00 \\
M.E. (kcal/kg) & 2800 & 2800 \\
Crude fat (\%) & 5.15 & 5.47 \\
Crude fiber (\%) & 2.44 & 2.56 \\
Calcium (\%) & 3.75 & 3.75 \\
Total Phosphorus (\%) & 0.78 & 0.80 \\
Available Phosphorus (\%) & 0.50 & 0.50 \\
Lysine (\%) & 1.02 & 0.94 \\
Methionine + Cystine (\%) & 0.79 & 0.77 \\
\hline
\end{tabular}

Digestion trial was conducted to determine the digestibility of the feed nutrients. Six birds from each treatment were randomly selected and placed in individual cages. They were fed their respective diets with $0.2 \%$ chromic oxide as indicator for 7 days. On the $3^{\text {rd }}$ to $6^{\text {th }}$ day of feeding, feces were collected using stainless trays installed under each cage. At the end of the collection period, fecal samples collected from each replicate of each treatment were dried, and subjected to proximate analysis and chromic oxide determination. Apparent digestibility of each nutrient was calculated in relation to egg production, egg weight, feed consumption, feed efficiency, body weight gain, shell thickness and yolk pigmentation, mortality, and income over feed cost calculated. All the data collected were subjected to statistical analysis using the general linear model (GLM) procedure of the SAS Institute (1988). Tests of significant differences among treatment means were done using the Duncan's Multiple Range Test (DMRT).

\section{RESULTS AND DISCUSSION}

\section{Chemical analysis of the layer diet}

The proximate, calcium and phosphorus analyses of the basal layer diet and diet with reduced crude protein supplemented with different levels of acid protease is shown in Table 2 . The actual analyses of the diets confirm closely with their calculated analysis in terms of crude protein, ether extract and calcium. Crude fiber and phosphorus analyses are slightly higher than the calculated. 
Table 2. Proximate, calcium and phosphorus analyses of layer's basal diet and diet with reduced protein used in the study

\begin{tabular}{|lcr|}
\hline Chemical components & \multicolumn{2}{c}{ Percent in diet } \\
\hline Dry Matter & Basal & \multicolumn{1}{c|}{ Reduced CP Diet } \\
Crude Protein & 90.28 & 90.52 \\
Ether extracts & 18.28 & 17.12 \\
Crude fiber & 5.61 & 5.50 \\
Nitrogen-free-extract & 4.71 & 6.73 \\
Ash & 64.24 & 65.69 \\
Calcium & 7.16 & 3.96 \\
Total phosphorus & 3.88 & 3.90 \\
\hline
\end{tabular}

\section{Digestibility study}

Coefficients of digestibility of crude protein (CP), ether extract (EE), crude fiber (CF) and nitrogen-freeextract (NFE) of basal layer diet and diets with reduced CP supplemented with different levels of acid protease are shown in Table 3. A significant decrease in digestibility coefficients of CP, EE, CF, and NFE were observed when crude protein of the diet was reduced by $1 \%$ relative to the basal diet. Protease supplementation of reduced CP diet with increasing levels significantly increased the digestibility coefficients of CP and EE but not CF. Digestibility coefficients of NFE significantly increased with $0.075 \%$ and $0.1 \%$ protease but not with $0.05 \%$ protease supplementation of the reduced CP diets.

Table 3. Digestion coefficients (\%) of crude protein, ether extract, crude fiber and nitrogen-free- extract of layers fed basal diet and diet with reduced crude protein supplemented with different levels of acid protease

\begin{tabular}{|lcccc|}
\hline Treatments & \multicolumn{3}{c|}{ Digestion coefficients (\%) } \\
\cline { 2 - 5 } & Crude protein & Ether extract & Crude fiber & Nitrogen-free- extract \\
\hline Basal diet & $79.80 \mathrm{a}$ & $77.78 \mathrm{a}$ & $64.88 \mathrm{a}$ & $87.98 \mathrm{a}$ \\
Diet with reduced crude protein & $74.16 \mathrm{~b}$ & $74.65 \mathrm{~b}$ & $56.42 \mathrm{~b}$ & $84.05 \mathrm{~b}$ \\
$\begin{array}{l}\text { Diet with reduced crude protein } \\
+0.05 \% \text { protease }\end{array}$ & $78.97 \mathrm{a}$ & & $60.79 \mathrm{ab}$ & $84.28 \mathrm{~b}$ \\
$\begin{array}{l}\text { Diet with reduced crude protein } \\
+0.075 \% \text { protease }\end{array}$ & $78.77 \mathrm{a}$ & $78.40 \mathrm{a}$ & $62.31 \mathrm{ab}$ & $87.35 \mathrm{a}$ \\
$\begin{array}{l}\text { Diet with reduced crude protein } \\
+0.1 \% \text { protease }\end{array}$ & $80.24 \mathrm{a}$ & $78.98 \mathrm{a}$ & & $86.67 \mathrm{a}$ \\
\hline
\end{tabular}

Means within column having different superscripts are significant at $\mathrm{P}<0.05$

In general, increasing the levels of protease in diets with reduced crude protein increased the digestibility of nutrients to the level of the basal diet. Results demonstrate that the reduction of CP in diet decreased the digestibility of nutrients, while protease supplementation of diets with the reduced crude protein enhanced the digestibility of all the nutrients. The enhancement in the digestibility of nutrients could be attributed to the exogenous protease, which acted together with the endogenous proteolytic enzymes. The results are in conformity with the findings of Nasi (1988) who observed improved protein utilization of hens fed enzyme supplemented barley and oats diets. Brenes et al. (1993) observed an improvement in the crude protein digestibility of enzyme supplemented raw, autoclaved and dehulled lupins in chicken diets. Addition of enzymes to the layer diets increased availability of energy found significant differences in protein, starch and ME content of corn samples with different densities when supplemented with enzymes (Baido et al., 1997).

\section{Egg production}

Table 4 presents the biweekly and overall average egg production of layers fed basal diet and diets with reduced crude protein supplemented with different levels of acid protease from 24 to 40 weeks of age. Results showed that except on first and sixth biweekly feeding periods, reduction of the crude protein of the layer diet by $1 \%$ generally depressed the biweekly and overall average egg production of the pullets. Significant reduction in egg production was observed only on the third biweekly period. 
Protease supplementation of reduced crude protein diet generally increased the biweekly egg production of the pullets in most periods of the trial. Increased level of protease supplementation of the reduced crude protein diet generally but not significantly increased the biweekly egg production of the pullets. The overall average egg production of the pullets was slightly depressed with reduction of crude protein in the diet. Supplementation of diet with $0.1 \%$ protease significantly increased the overall egg production of the pullets relative to those fed reduced crude protein diet with no enzyme supplement. Lower levels of inclusion of protease $(0.05 \%$ and $0.075 \%)$ showed no significant improvement on the overall egg production of the pullets.

Table 4. Biweekly and overall average egg production of pullets fed basal diet and diets with reduced crude protein supplemented with different level of acid proteases from 24 to 40 weeks of age

\begin{tabular}{|c|c|c|c|c|c|c|c|c|c|}
\hline \multirow{3}{*}{ Treatments } & \multicolumn{9}{|c|}{ Percent egg production } \\
\hline & \multicolumn{9}{|c|}{ Feeding period bi-weekly } \\
\hline & 1 & 2 & 3 & 4 & 5 & 6 & 7 & 8 & Overall \\
\hline Basal diet & 85.61 & 96.43 & $94.84 \mathrm{a}$ & 93.65 & 93.65 & 92.46 & $94.84 \mathrm{ab}$ & 92.46 & $92.73 \mathrm{ab}$ \\
\hline $\begin{array}{l}\text { Diet with reduced } \\
\text { crude protein }\end{array}$ & 89.30 & 92.06 & $86.42 b$ & 90.47 & 90.47 & 93.65 & $92.14 \mathrm{ab}$ & 89.28 & $90.62 \mathrm{~b}$ \\
\hline $\begin{array}{l}\text { Diet with reduced crude } \\
\text { protein }+0.05 \% \text { protease }\end{array}$ & 91.50 & 92.46 & $89.28 \mathrm{ab}$ & 91.26 & 91.26 & 90.49 & $93.65 \mathrm{ab}$ & 88.57 & $90.85 b$ \\
\hline $\begin{array}{l}\text { Diet with reduced crude } \\
\text { protein }+0.075 \% \text { protease }\end{array}$ & 88.49 & 94.44 & $88.49 \mathrm{ab}$ & 92.06 & 92.06 & 90.87 & $89.68 \mathrm{~b}$ & 91.66 & $91.00 \mathrm{~b}$ \\
\hline $\begin{array}{l}\text { Diet with reduced crude } \\
\text { protein }+0.1 \% \text { protease }\end{array}$ & 86.55 & 96.03 & $94.44 a$ & 95.23 & 95.23 & 94.44 & $95.63 \mathrm{a}$ & 95.24 & $94.05 \mathrm{a}$ \\
\hline
\end{tabular}

Means within column having different superscripts differs significantly $\mathrm{p}<0.05$

The result suggests that egg production was slightly depressed with $1 \%$ reduction of CP in diet. Supplementation of diets with $0.1 \%$ protease significantly improved the egg production of the pullets. The decrease in egg production rate of pullets with reduction of crude protein in diet could be due to the decreased digestibility of nutrients while the significant improvement in egg production rate of pullets at $0.1 \%$ protease could be attributed to the increased digestibility of nutrients as shown in Table 3. The results are supported by the report of Nasi (1988) who observed significant improvement in egg production of hen fed diets supplemented with cellulase, beta-glucanase and protease. Jacob et al. (2000) noted that the enzyme supplementation of reduced crude protein diet did not adversely affect egg production. An improvement in egg production of pullets was reported with enzyme supplementation of cereal based diets (Luis,1998).

\section{Egg weight}

Table 5 presents the average biweekly and overall average egg weights of pullets fed basal diet and diets with reduced crude protein supplemented with different levels of acid protease from 24 to 40 weeks of age. One percent reduction of crude protein of the diet showed no significant effect on the average biweekly as well as overall average egg weight of eggs produced by pullets. No consistent trends in egg weights were seen during the entire biweekly periods with the reduction of crude protein in diet. Overall average egg weight was slightly increased with reduction of crude protein in diet of pullets. Except on biweekly periods seventh and eighth at $0.075 \%$ protease, no consistent and significant effect on egg weights of pullets was seen during the entire biweekly periods. Likewise except with pullets fed $0.05 \%$ protease, egg produced by pullets fed diets with $0.075 \%$ and $0.1 \%$ protease supplementation was slightly heavier than those fed similar diet with no protease.

Results showed that neither the reduction in crude protein nor protease supplementation of reduced CP diets influenced the size of egg produced by the pullets. This observation is in consonance with the findings of Nasi (1988) and Dong (1997), who found no significant effect on the weight of eggs laid by pullets fed diets supplemented with enzyme. Pullets fed cereal- based diets supplemented with multi enzymes produced eggs of heavier weights than those fed diets without enzymes supplement (Brufau et al., 1993). This difference in egg weight could be due to the different diets and kind and level of enzymes used. 
Table 5. Biweekly and overall average egg weight of pullets fed basal diet and diets with reduced crude protein supplemented with different level of acid proteases from 24 to 40 weeks of age

\begin{tabular}{|c|c|c|c|c|c|c|c|c|c|}
\hline \multirow{3}{*}{ Treatments } & \multicolumn{9}{|c|}{ Egg weight (g) } \\
\hline & \multicolumn{9}{|c|}{ Feeding period bi-weekly } \\
\hline & 1 & 2 & 3 & 4 & 5 & 6 & 7 & 8 & Overall \\
\hline Basal diet & 54.33 & 55.41 & 57.57 & 57.53 & 57.55 & 57.79 & $57.52 \mathrm{~b}$ & $57.55 b$ & $56.87 \mathrm{ab}$ \\
\hline $\begin{array}{l}\text { Diet with reduced } \\
\text { crude protein }\end{array}$ & 56.00 & 56.46 & 56.36 & 57.21 & 58.66 & 58.39 & $58.38 \mathrm{~b}$ & $58.38 \mathrm{~b}$ & $57.50 \mathrm{ab}$ \\
\hline $\begin{array}{l}\text { Diet with reduced crude } \\
\text { protein }+0.05 \% \text { protease }\end{array}$ & 53.91 & 54.63 & 56.18 & 57.49 & 57.39 & 57.57 & $58.12 \mathrm{~b}$ & $58.79 \mathrm{~b}$ & $56.75 b$ \\
\hline $\begin{array}{l}\text { Diet with reduced crude } \\
\text { protein }+0.075 \% \text { protease }\end{array}$ & 54.60 & 56.14 & 58.50 & 59.24 & 59.75 & 59.68 & $60.92 \mathrm{a}$ & $61.41 \mathrm{a}$ & $58.82 \mathrm{a}$ \\
\hline $\begin{array}{l}\text { Diet with reduced crude } \\
\text { protein }+0.1 \% \text { protease }\end{array}$ & 54.73 & 58.44 & 57.53 & 58.16 & 58.66 & 59.33 & $58.97 \mathrm{ab}$ & $59.59 \mathrm{ab}$ & $58.19 \mathrm{ab}$ \\
\hline
\end{tabular}

Means within column having different superscripts differs significantly $\mathrm{p}<0.05$

\section{Feed consumption}

Table 6 presents the average biweekly and overall average feed consumption of pullets fed basal diet and diets with reduced crude protein supplemented with different levels of acid protease from 24 to 40 weeks of age. Results showed that except on the second and fourth biweekly feeding periods, reduction of crude protein of the diet generally increased the biweekly as well as the overall average feed consumption of the pullets. Significant increase in feed consumption of pullets with reduction of dietary protein was observed only during the eighth biweekly feeding period. Protease supplementation of reduced crude protein diets generally decreased the feed consumption of pullets during the entire feeding periods except the feeding period eighth, in which it significantly decreased at all levels of protease supplementation relative to those fed the reduced CP diet with no protease. Likewise, protease supplementation of diets with reduced crude protein decreased consistently but not significantly the overall average feed consumption of pullets.

Table 6. Biweekly and overall average feed consumption ( $\mathrm{g} / \mathrm{day}$ ) of pullets fed basal diet and diets with reduced crude protein supplemented with different level of acid proteases from 24 to 40 weeks of age

\begin{tabular}{|c|c|c|c|c|c|c|c|c|c|}
\hline \multirow{3}{*}{ Treatments } & \multicolumn{9}{|c|}{ Feed consumption (g/day) } \\
\hline & \multicolumn{9}{|c|}{ Feeding period bi-weekly } \\
\hline & 1 & 2 & 3 & 4 & 5 & 6 & 7 & 8 & Overall \\
\hline Basal diet & 98.12 & 98.28 & 97.74 & 99.23 & 99.90 & 102.09 & 102.70 & $102.29^{\mathrm{b}}$ & 99.92 \\
\hline $\begin{array}{l}\text { Diet with reduced } \\
\text { crude protein }\end{array}$ & 98.31 & 97.77 & 98.43 & 98.92 & 100.08 & 102.76 & 102.88 & $103.87^{\mathrm{a}}$ & 100.41 \\
\hline $\begin{array}{l}\text { Diet with reduced crude } \\
\text { protein }+0.05 \% \text { protease }\end{array}$ & 98.52 & 98.29 & 97.58 & 98.34 & 99.00 & 101.12 & 101.74 & $101.56^{b c}$ & 99.52 \\
\hline $\begin{array}{l}\text { Diet with reduced crude } \\
\text { protein }+0.075 \% \text { protease }\end{array}$ & 96.62 & 97.05 & 96.71 & 98.20 & 99.06 & 100.62 & 101.19 & $100.48^{\mathrm{cd}}$ & 98.75 \\
\hline $\begin{array}{l}\text { Diet with reduced crude } \\
\text { protein }+0.1 \% \text { protease }\end{array}$ & 96.71 & 96.88 & 97.14 & 98.16 & 98.40 & 100.98 & 101.16 & $100.06^{\mathrm{d}}$ & 98.69 \\
\hline
\end{tabular}

Means within column having different superscripts differs significantly $\mathrm{p}<0.05$

Results showed that pullets tended to consume more feeds when fed reduced crude protein diet and tended to consume less feeds when diets were supplemented with protease. The slight increase in feed consumption of pullets fed diets with reduced crude protein could be due to the tendency of the birds to eat more to compensate for lower crude protein content of the diet. In contrast, the slight decrease in feed consumption of pullet fed protease-supplemented diets could be due to the increased digestibility of nutrients as presented in Table 3. The results are supported by the findings of Luis (1998) who did not find significant effect on feed consumption of pullets fed enzyme-supplemented diets. A decrease in feed consumption of 
pullets was observed when diets were supplemented with multi enzymes (Dong, 1997). Similarly, Reddy (1999) reported decreased feed consumption of pullets when corn-soya based diets were supplemented with protease.

\section{Feed efficiency}

Table 7 presents the average biweekly and overall average feed efficiency of pullets fed basal diet and diets with reduced crude protein supplemented with different levels of acid protease from 24 to 40 weeks of age. One percent reduction of crude protein in diet generally depressed the biweekly and overall feed efficiency of the pullets during the entire feeding periods. Statistical analysis of the data showed no significant differences between the two treatments in the biweekly and overall feed efficiency except on the third biweekly period. Protease supplementation of diets with the reduced crude protein generally improved the feed efficiency of pullets. Statistical analysis of the data showed no significant differences among treatments in feed efficiency except on periods third at $0.1 \%$, sixth at $0.05 \%$ and eighth $0.075 \%$ and $0.1 \%$ protease. Protease supplementation of the reduced crude protein diet with $0.1 \%$ significantly enhanced the overall average feed efficiency of pullets relative to those fed reduced crude protein diet with no supplementary protease. Lower levels $(0.05 \%$ and $0.075 \%$ protease) of protease supplementation of the diets gave no significant improvement in the feed efficiency of the pullet.

The results indicate that reduction in crude protein of diet by one percent slightly depressed the feed efficiency of the pullets. On the other hand, protease supplementation generally improved the feed efficiency of the pullets. The depression in feed efficiency with reduction of CP in diet could be due to increased feed consumption and decreased egg production of pullets. The improvement in feed efficiency with protease supplementation of diets could be attributed to the increased egg production and decreased feed consumption of pullets. The results confirm the findings of Cresswell (1997) and Nasi (1988) who reported a significant improvement in feed efficiency of hens fed corn-based diets with multi-enzyme supplementation. An insignificant improvement in feed efficiency of pullets was reported with multi-enzyme supplementation of diets (Luis, 1997). Reddy (1999) reported a significant improvement in feed efficiency of layers fed diets supplemented with protease.

Table 7. Biweekly and overall average feed efficiency ( $\mathrm{kg}$ feed $/ \mathrm{kg}$ eggs) of pullets fed basal diet and diets with reduced crude protein supplemented with different level of acid proteases from 24 to 40 weeks of age

\begin{tabular}{|c|c|c|c|c|c|c|c|c|c|}
\hline \multirow{3}{*}{ Treatments } & \multicolumn{9}{|c|}{ Feed efficiency } \\
\hline & \multicolumn{9}{|c|}{ Feeding period bi-weekly } \\
\hline & 1 & 2 & 3 & 4 & 5 & 6 & 7 & 8 & Overall \\
\hline Basal diet & 2.08 & $1.84 \mathrm{ab}$ & $1.81 \mathrm{~b}$ & $1.84 \mathrm{ab}$ & 1.86 & $1.90 \mathrm{ab}$ & 1.90 & $1.93 \mathrm{ab}$ & $1.90 \mathrm{abc}$ \\
\hline $\begin{array}{l}\text { Diet with reduced } \\
\text { crude protein }\end{array}$ & 1.99 & $1.90 \mathrm{ab}$ & $1.98 \mathrm{a}$ & $1.93 \mathrm{a}$ & 1.88 & $1.91 \mathrm{ab}$ & 1.90 & $2.02 \mathrm{a}$ & $1.93 \mathrm{ab}$ \\
\hline $\begin{array}{l}\text { Diet with reduced crude } \\
\text { protein }+0.05 \% \text { protease }\end{array}$ & 2.03 & $2.02 \mathrm{a}$ & $1.98 \mathrm{a}$ & $1.90 \mathrm{ab}$ & 1.97 & $1.95 \mathrm{a}$ & 1.88 & $1.98 \mathrm{a}$ & $1.96 \mathrm{a}$ \\
\hline $\begin{array}{l}\text { Diet with reduced crude } \\
\text { protein }+0.075 \% \text { protease }\end{array}$ & 1.97 & $1.84 \mathrm{ab}$ & $1.89 \mathrm{ab}$ & $1.81 \mathrm{ab}$ & 1.85 & $1.87 \mathrm{ab}$ & 1.89 & $1.79 \mathrm{~b}$ & $1.86 \mathrm{ba}$ \\
\hline $\begin{array}{l}\text { Diet with reduced crude } \\
\text { protein }+0.1 \% \text { protease }\end{array}$ & 2.06 & $1.79 \mathrm{~b}$ & $1.79 \mathrm{~b}$ & $1.78 \mathrm{~b}$ & 1.82 & $1.81 \mathrm{~b}$ & 1.80 & $1.77 \mathrm{~b}$ & $1.83 \mathrm{c}$ \\
\hline
\end{tabular}

Means within column having different superscripts differs significantly $\mathrm{p}<0.05$

\section{Shell thickness and yolk color scores}

Table 8 presents the average biweekly and overall average eggshell thickness of hens fed basal diet and diet with reduced crude protein supplemented with different levels of acid protease from 24 to 40 weeks of age. Results showed that $1 \%$ reduction of crude protein in diet had no significant effect on biweekly and overall average shell thickness of eggs produced during the entire feeding periods. Protease supplementation of the reduced crude protein diets likewise did not significantly affect the shell thickness of eggs produced during the entire feeding periods except the sixth and the seventh feeding periods. Eggshell thickness was significantly improved at $0.05 \%$ during sixth and $0.05 \%$ and $0.075 \%$ protease supplementation of diets during seventh 
biweekly feeding periods over those fed reduced CP diets with no protease. The overall average shell thickness of eggs was significantly improved at $0.075 \%$ but not at $0.05 \%$ and $0.1 \%$ protease supplement. In general, increased levels of protease in diets showed no consistent effect on the shell thickness of eggs produced.

The results indicate that reduction of crude protein of the diet failed to influence the shell thickness of eggs produced. Protease supplementation slightly improved the shell thickness of eggs produced. The results are in agreement with the findings of Luis (1997) and Dong (1997) who found no significant effect on the eggshell thickness of pullets fed diets with enzyme supplement. An improvement in eggshell thickness was observed with multi-enzyme supplementation of cereal-based diets of laying hens (Sirvydis et al., 1998). The difference in eggshell thickness could be due to the kind and level of enzyme present in the supplement.

Table 8. Biweekly and overall average egg shell thickness $(\mathrm{mm})$ of pullets fed basal diet and with reduced crude protein supplemented with different level of acid proteases from 24 to 40 weeks of age

\begin{tabular}{|c|c|c|c|c|c|c|c|c|}
\hline \multirow{3}{*}{ Treatments } & \multicolumn{7}{|c|}{ Egg shell thickness (mm) } & \multirow[b]{3}{*}{ Overall } \\
\hline & \multicolumn{7}{|c|}{ Feeding period bi-weekly } & \\
\hline & 1 & 2 & 3 & 4 & 5 & 6 & 7 & \\
\hline Basal diet & 0.398 & 0.395 & 0.380 & 0.386 & 0.373 & $0.371 \mathrm{c}$ & $0.367 \mathrm{c}$ & $0.381 b c$ \\
\hline Diet with reduced crude protein & 0.402 & 0.392 & 0.374 & 0.381 & 0.377 & $0.373 b c$ & $0.369 \mathrm{c}$ & $0.82 \mathrm{bc}$ \\
\hline $\begin{array}{l}\text { Diet with reduced crude } \\
\text { protein }+0.05 \% \text { protease }\end{array}$ & 0.408 & 0.397 & 0.377 & 0.386 & 0.76 & $0.395 \mathrm{a}$ & $0.381 \mathrm{ab}$ & $0.389 \mathrm{ab}$ \\
\hline $\begin{array}{l}\text { Diet with reduced crude protein } \\
+0.075 \% \text { protease }\end{array}$ & 0405 & 0.399 & 0.388 & 0.395 & 0.390 & $0.384 \mathrm{ab}$ & $0389 \mathrm{a}$ & $0.393 \mathrm{a}$ \\
\hline $\begin{array}{l}\text { Diet with reduced crude protein } \\
+0.1 \% \text { protease }\end{array}$ & 0392 & 0.390 & 0.384 & 0.386 & 0.372 & $0.376 \mathrm{bc}$ & $0.374 \mathrm{bc}$ & $0.380 \mathrm{c}$ \\
\hline
\end{tabular}

Means within column having different superscripts differs significantly $\mathrm{p}<0.05$

Table 9 presents the biweekly and overall average yolk color of eggs of pullets fed basal diet and diets with reduced crude protein supplemented with different levels of protease from 24 to 40 weeks of age. Except on second and fourth biweekly periods reduction of crude protein of diet decreased the biweekly as well as the overall average yolk color of eggs of pullets. Statistical analysis of the data showed that reduction of $\mathrm{CP}$ of diet significantly decreased yolk color of eggs only during the fifth and sixth biweekly periods. Protease supplementation of reduced CP diets showed no consistent trends in biweekly as well as overall average yolk color of eggs produced.

Table 9. Biweekly and overall average egg yolk color (Roche color fan) of pullets fed basal diet and diets with reduced crude protein supplemented with different level of acid proteases from 24 to 40 weeks of age

\begin{tabular}{|c|c|c|c|c|c|c|c|c|}
\hline \multirow{3}{*}{ Treatments } & \multicolumn{7}{|c|}{ Egg yolk color } & \multirow[b]{3}{*}{ Overall } \\
\hline & \multicolumn{7}{|c|}{ Feeding period bi-weekly } & \\
\hline & 1 & 2 & 3 & 4 & 5 & 6 & 7 & \\
\hline Basal diet & $8.16 \mathrm{~b}$ & $7.83 \mathrm{~b}$ & 8.11 & 8.27 & $8.38 \mathrm{a}$ & $8.33 \mathrm{a}$ & $8.38 \mathrm{ab}$ & $8.21 \mathrm{ab}$ \\
\hline Diet with reduced crude protein & $8.11 \mathrm{~b}$ & $8.00 \mathrm{~b}$ & 7.88 & 8.38 & $7.77 \mathrm{~b}$ & $7.88 \mathrm{~b}$ & $8.16 \mathrm{~b}$ & $8.03 \mathrm{ab}$ \\
\hline $\begin{array}{l}\text { Diet with reduced crude protein } \\
+0.05 \% \text { protease }\end{array}$ & $8.85 \mathrm{a}$ & $8.50 \mathrm{a}$ & 8.33 & 8.27 & $7.83 \mathrm{~b}$ & $7.83 \mathrm{~b}$ & $8.22 \mathrm{~b}$ & $8.26 \mathrm{ab}$ \\
\hline $\begin{array}{l}\text { Diet with reduced crude protein } \\
+0.075 \% \text { protease }\end{array}$ & $7.83 \mathrm{~b}$ & $8.44 \mathrm{a}$ & 8.11 & 8.05 & $7.66 \mathrm{~b}$ & $7.38 \mathrm{c}$ & $8.50 \mathrm{ab}$ & $7.99 \mathrm{~b}$ \\
\hline $\begin{array}{l}\text { Diet with reduced crude protein } \\
+0.1 \% \text { protease }\end{array}$ & $8.27 \mathrm{ab}$ & $8.66 \mathrm{a}$ & 8.33 & 7.94 & $7.05 \mathrm{ab}$ & $8.05 \mathrm{ab}$ & $8.61 \mathrm{a}$ & $8.13 \mathrm{a}$ \\
\hline
\end{tabular}

Means within column having different superscripts differs significantly $\mathrm{p}<0.05$

The above results indicate that the yolk color of eggs was not influenced either by reduction of crude protein of diet or protease supplementation of reduced CP diet except during second biweekly feeding period. Significant increase in yolk color during some biweekly periods indicates that the protease was able to release pigments responsible for yolk color development. The observations are in agreement with the findings of Igbasan and Guenter (1996) who found no significant effect on yolk color of eggs fed wheat-peas based diets 
supplemented with enzymes. Sorensen (1996) also did not find significant effect on egg yolk color of eggs fed maize-sunflower diets supplemented with enzymes.

\section{Initial body weight and body weight gain}

Table 10 presents initial body weight and body weight gain of pullets fed basal diet and diets with reduced crude protein supplemented with different levels of protease from 24 to 40 weeks of age. Reduction of crude protein of diet slightly decreased the body weight gain of pullets. Body weight gain of pullets inconsistently decreased with increased level of protease supplementation to the reduced crude protein diet. No significant differences in initial, final and body weight gain of hens were observed among treatments either with the reduction of $\mathrm{CP}$ or protease supplementation of reduced $\mathrm{CP}$ diet.

Although not significantly different, results indicate that reduction of crude protein of diet decreased body weight gain of pullets. Likewise, enzyme supplementation of reduced CP diet also decreased the body weight gain of the pullets. The decrease in body weight gain of pullets with reduction of dietary protein could be due to decreased digestibility of nutrients as shown in Table 3. The decreased body weight gain in pullets fed protease-supplemented diets could be due to slightly increased egg production as shown in Table 4. The results confirm the findings of Luis (1998) and Pan et al. (1998), who observed no significant increase or decrease body weight gain in pullets fed diets supplemented with enzymes.

Table 10. Mean initial, final, and body weight gain of pullets fed basal diet and diets with reduced crude protein supplemented with different levels of proteases from 24 to 40 weeks of age

\begin{tabular}{|lccc|}
\hline Treatments & \multicolumn{3}{c|}{ Body weight (g) } \\
\cline { 2 - 4 } & Initial & Final & Gain \\
\hline Basal diet & 1368.42 & 1534.21 & 165.78 \\
Diet with reduced crude protein & 1359.47 & 1505.78 & 146.31 \\
Diet with reduced crude protein $+0.05 \%$ protease & 1341.47 & 1477.63 & 132.36 \\
Diet with reduced crude protein $+0.075 \%$ protease & 1384.73 & 1500.00 & 115.26 \\
Diet with reduced crude protein $+0.1 \%$ protease & 1356.31 & 1485.52 & 129.21 \\
\hline
\end{tabular}

Means within column having different superscripts differs significantly $\mathrm{p}<0.05$

\section{Income over feed cost (IOFC)}

Table 11 presents the IOFC of pullets fed basal diet and diets with reduced crude protein supplemented with different levels of acid protease from 24 to 40 weeks of age. Results showed that income over feed cost of pullets decreased with the reduction of crude protein in diet. Protease supplementation of reduced crude protein diets of pullets with increased levels of supplements improved consistently the IOFC.

The results indicate that IOFC decreased with reduction of crude protein of the diet. Moreover, IOFC increased with protease supplementation of reduced crude protein diet. The decrease in income over feed cost with reduction of crude protein in diet could be due to increased feed intake and feed cost relative to those fed basal diet. On the other hand, the increase in income over feed cost of pullets with protease supplementation of reduced crude protein diets could be attributed to the decreased feed intake and total feed cost relative to those pullets fed reduced crude protein diet. Results are in agreement with the findings of Dong (1997), who reported a slightly higher income over feed cost of layers fed corn-soybean based diets supplemented with enzymes. This result contradicts the findings of Luis (1997), who observed a lower IOFC of layers fed cornbased diets supplemented with enzymes. The decrease in income over feed cost in their study could be due to different diet composition and the kind and level of enzyme present in the supplement. 
Table 11. Income over feed cost (IOFC) of pullets fed basal diet and diets with reduced crude protein supplemented with different levels of acid protease from 24 to 40 weeks of age

\begin{tabular}{|c|c|c|c|c|c|}
\hline Treatments & $\begin{array}{c}\text { Total feed } \\
\text { consumed (kg) }\end{array}$ & $\begin{array}{l}\text { Total feed } \\
\text { cost }(\mathrm{PhP})\end{array}$ & $\begin{array}{l}\text { Total eggs } \\
\text { (dozens) }\end{array}$ & $\begin{array}{l}\text { Income from } \\
\text { sale of eggs }\end{array}$ & $\begin{array}{l}\text { IOFC } \\
(\mathrm{PhP})\end{array}$ \\
\hline Basal diet & 11.00 & 112.75 & 8.96 & 296.34 & 183.59 \\
\hline Diet with reduced crude protein & 11.25 & 112.95 & 8.60 & 284.00 & 171.05 \\
\hline $\begin{array}{l}\text { Diet with reduced crude protein } \\
+0.05 \% \text { protease }\end{array}$ & 11.00 & 112.04 & 8.49 & 280.23 & 168.18 \\
\hline $\begin{array}{l}\text { Diet with reduced crude protein } \\
+0.075 \% \text { protease }\end{array}$ & 11.10 & 110.55 & 8.80 & 290.51 & 179.96 \\
\hline $\begin{array}{l}\text { Diet with reduced crude protein } \\
+0.1 \% \text { protease }\end{array}$ & 11.07 & 111.20 & 9.00 & 2.97 .10 & 185.90 \\
\hline
\end{tabular}

0 Standard sized eggs calculated on the basis of 56.60 grams, 1 Price of protease 636.00 PhP per kg, 2 Sale of eggs 33.00 PhP per dozen, 3 Feed cost 9.94 and $9.73 \mathrm{PhP}$, respectively for basal and reduced crude protein diets

\section{CONCLUSIONS}

One percent reduction of crude protein of diet of pullet significantly decreased the digestibility of all nutrients. Both biweekly and overall average egg production, feed consumption, egg weight, feed efficiency, eggshell thickness, yolk color and body weight gain were not significantly affected by dietary reduction of crude protein. Income over feed cost decreased with reduction of crude protein of the diet. Protease supplementation of reduced CP diets significantly improved the CP and EE digestibility of diets and generally increased the biweekly and overall egg production in most periods of the trial. Egg weight, feed consumption, and yolk color were not significantly influenced by protease supplementation of the reduced CP diets. Feed efficiency was significantly improved with $0.1 \%$ protease, while eggshell thickness was significantly improved with $0.075 \%$ protease supplementation of diets. Income over feed cost increased with dietary supplementation of protease. Increased level of protease supplementation of reduced CP diets consistently improved the digestibility of nutrients, overall average egg production and decreased feed consumption. Egg weight and feed efficiency were slightly improved with $0.075 \%$ and $0.1 \%$ protease supplementation of diet. Eggshell thickness was significantly improved with $0.075 \%$ protease Yolk color was not significantly influenced by increased protease supplementation of the diet. Income over feed cost was consistently increased with protease supplementation. The crude protein of layer diets could be reduced by one percent provided that they are supplemented with protease. Optimum level of inclusion of protease is $0.1 \%$ for layers. Enzyme activity must be accurately determined before it is used.

\section{ACKNOWLEDGMENTS}

The author wishes deep sense of gratitude to the editor, Director of research, Dean of Institute of Agriculture and Animal Sciences, and all other staffs who directly or indirectly helped in finalizing and publishing this paper.

\section{REFERENCES CITED}

Baidoo, S. K, Y. G. Lin and R. R. Grandhi. 1997. Exogenous microbial enzymes and hulless barley utilization by pigs. Proceedings Manitoba Swine Seminar. Manitoba University Winnipeg, 11: 135-140.

Brenes, A., M. Smith, W. Guenter and R. R. Marquardt. 1993. Effect of enzyme supplementation on the performance and digestive tract size of broiler chicken fed wheat and barley-based diets. Poult. Sci. 72: $1731-1739$.

Brufau, J; A. M. Perez-Vendrell and D E. Esteve-Garcia.1993. Performance of laying hens as affected by the supplementation of a barley-based diet with a crude enzyme preparation from Trichoderma viride. Can J. Anim. Sci. 74: 129-133.

Close, W. H. 1996. Enzymes in action. Pigs Missets 12 (7): 21-24.

Cowieson, A. J., T. Acamoic and M. R. Ford. 2000. Enzyme supplementation of diets containing Camelina sativa meal for poultry. British Poultry Sci. 41:689-690. 
Creswell, D. A. 1997. The supplemented enzymes for laying hens fed wheat and barley diets (unpublished data). Finfeed International Ltd. U.K, and Univertsity of Queensland, Gatton College, Australia.

Dong, D. D. 1997. Enzyme supplementation of corn-based and wheat-based layer diets. M.S. Thesis. UPLB, College, Laguna, Philippines.

Igbasan, F. A. and W. Guenter. 1996 Influence of micronization, dehulling and enzymes supplementation on the nutritional value of peas for laying hens. Poultry Sci. 70: 331-337

Jacob, J.P., S. Ibrahim, R. Blair, H. Namkung and I.K. Paik. 2000. Using enzyme-supplemented, reduced protein diets to decrease nitrogen and phosphorus excretion of white leghorn hens. Asian Aus. J. Ani. Sci. 13 (12): 1743-1749

Luis, A.M.B. 1998. Enzyme supplementation of corn-soybean based broiler and layer diets. Graduate Thesis, UPLB, Philippines.

Luis, V.B. 1997. Carbohydrase supplementation of broiler and layer diets containing different kinds of soybean meal. Graduate Thesis, UPLB, Philippines.

Marquardt,R.R., D. Boros,W.Guenter and G. Crow. 1994. The nutritive value of barley, rye, wheat, and corn for chicks as affected by the use of a Trichoderma reesei enzyme preparation. Anim. Feed and Sci. Technol. 45:363-378

Nasi, M. 1988. Enzyme supplementation of laying hen diets based on barley and oats. In: T. P. Lyons (ed.) Biotechnology in the Feed Industry. Proceedings of Altech's Symposium Nashville, U.S.A. pp. 199-204.

Pan, C. F., F. A. Igbason, W. Guenter., R. R. Marquardt. 1998. The effects of enzyme and inorganic phosphorus supplements in wheat and rye-based diets on laying hen performance, energy and phosphorus availability. Poultry Science 77:83-89.

Reddy, C.V. 1999. Improving the nutritional quality of feed. Poultry International Vol. 38, No. 13.

SAS Institute. 1988. SAS/Stat R User's Guide. Version 8, SAS Institute Inc. Cary, North Carolina, USA.

Sirvydis, V., D. Vencius., Gudavaviciute., R, Sabalionyte 1998. Effect of multienzyme compositions on the eggshell quality of laying hens. Vilnuis Pedagogical University, Vilnuis, Lithuania.

Sorensen, P. 1996. Sunflower + enzymes = soybeans ? New roles for arabinases, pectinases, and xylanases. Feed Intl. 17: 24-28. 